\title{
Elucidating Environment Management Intervention Benefits and Underpinning Factors among Uganda's Albertine Rift Communities
}

\author{
Priscilla Nyadoi ${ }^{*}$, Laster Stoney Ogola ${ }^{1}$, Harriet Kyakyo ${ }^{1}$, John Bosco Lamoris Okullo ${ }^{1,2}$ \\ ${ }^{1}$ Uganda Wildlife Society, Kampala, Uganda \\ ${ }^{2}$ School of Forestry, Environment and Geographical Sciences, Makerere University, Kampala, Uganda \\ Email: ^msnyadoi@yahoo.com, jblokullo@gmail.com
}

How to cite this paper: Nyadoi, P., Ogola, L. S., Kyakyo, H., \& Okullo, J. B. L. (2020). Elucidating Environment Management Intervention Benefits and Underpinning Factors among Uganda's Albertine Rift Communities. Journal of Geoscience and Environment Protection, 8, 157-174.

https://doi.org/10.4236/gep.2020.810012

Received: July 24, 2020

Accepted: October 19, 2020

Published: October 22, 2020

Copyright $\odot 2020$ by author(s) and Scientific Research Publishing Inc. This work is licensed under the Creative Commons Attribution International License (CC BY 4.0).

http://creativecommons.org/licenses/by/4.0/ (c) (i) Open Access

\begin{abstract}
Environmental management intervention benefits have been found to depend on beneficiaries' unique socioeconomic-environmental factors and understanding these helps generate knowledge guidelines for designing, planning and implementation of new interventions. The Ecosystems Alliance (EA) Project in Uganda's Albertine Rift promoted interventions including, resource access from protected areas, monitoring oil companies' compliance to set environmental standards, tree planting, lake bank restoration, bee keeping, hay for livestock feeding and cages to shelter communities from crocodiles for four years in Buliisa, Hoima and Kasese district, to, build management capacity of the local communities and institutions to remedy the region's environment and natural resources which were declining. At the end of the project we interviewed 56 representatives of the project beneficiaries individually and obtained data on benefit level, factors underpinning and perceived livelihoods and environmental impacts of the interventions and used Statistical Package for Social Scientists (SPSS) version 16 (Bryman \& Cramer, 2009) to generate percentages (\%), correlations with $p \leq 0.05$ considered as significant relationship on these. As results, $\geq 90 \%$ of respondents in districts benefited from EA project interventions. Beneficiaries perceived the interventions that enhanced their household incomes and this was especially important for those who were not educated ( $p=0.01$, for education level); the environment management capacity and this was especially important for women $(p=0.05$, for sex) and for households of $4-6$ members ( $p=0.02$ with family size); the reduced conflicts with wildlife and this was especially important for households with $4-6$ members $(p=0.02)$ and for people who de-
\end{abstract}


pended on wetlands/wildlife resources ( $p=0.00$ for both cases) among others. Among constraints to benefit, time of intervention and climatic conditions was especially important among crop farmers $(p=0.04$ with occupation) while, intervention not meeting expectation was a factor among beneficiaries in the age group $18-31$ and $61-70$ years old ( $p=0.01$, for age). The respondents recommended future initiatives start with research to determine interventions that match their environment, priority and expectations and these are distributed equitably after prior information/expectation management and technical capacity building.

\section{Keywords}

Natural Resources, Human Wildlife Conflicts, Tree Planting, Ecosystems

Alliance, Restoration, Protected Areas, Crop Farmers

\section{Introduction}

Various studies have reported that, ability to afford technologies, landholding size, gender, age, family size and education level, experience, knowledge and skills with regard to the technology influence beneficiaries adoption of the technologies/innovations and or new interventions (Abebe, 2007; Buyinza et al., 2008; Kugonza et al., 2009; Arikawei \& Nzeneri, 2013; Oloo, 2013). Generally it has been found that agricultural or natural resource management interventions that suit recipients' environment and meet their socioeconomic needs have been found to be well received (Buyinza et al., 2008; Tawari \& Davies, 2009). They will usually adopt and even take steps to acquire or protect the things they value and also reject technologies they deem not beneficial to them (Leach \& Kamangira, 1988-2001).

Earlier on in advances of biotechnology, Plunkett and Gaisford, 2000 for example reported that globally, people were not opening up to and were instead resisting biotechnology in food and agriculture because of lack of knowledge (Giannakas \& Fulton, 2000; Plunkett \& Gaisford, 2000). On the other hand, another study reported that the more knowledge people acquired about biotechnology the more some rejected acceptance and adoption (Bridges Trade Biores, 2003, 2006, 2007). In a related finding (Nirosha \& Brokel, 2016), lack of resources, incompatibility and complexity of new technology, socio-economic and cultural constraints, and inadequacies in extension intervention, technical training and information were the main constraints that influenced farmers' adoption of new technologies that were introduced to them. Additionally, like Leach and Kamangira (1988-2001), Nirosha and Broekel reported a methodology that included structured individual interviews of the beneficiaries and technical-extension workers who were involved in the programme they studied (Nirosha \& Brokel, 2016).

In analysis, Nirosha and Broekel explored for relationships between the far- 
mers' socioeconomic characteristics and the adoption parameters that were studied, a methodology deemed suitable for such survey studies, involving interviews and appraisals (Leach \& Kamangira, 1988-2001; Chromy \& Abeyesekera, 2005; Boyce \& Neale, 2006; Misturelli \& Heffernan, 2009) and findings of these studies all expose diverse relationships exist and unique factors influence peoples' adoption and benefit from environmental/agricultural and related technologies.

As is evidenced by all the reviews above, given new interventions, there will always be unique benefit and underpinning factors depending on beneficiaries' socio-economic and environmental settings. Identifying such factors will always generate useful knowledge guidelines for new environment management interventions. Therefore for the new EA project interventions that were implemented for four years in the Albertine Rift region of Uganda, that promoted environment management interventions which were aimed at building capacity of the local communities and institutions on proper environmental management to stem degradation and declines of natural resources and environment that was taking place, our study was worthwhile, for generation of knowledge which would provide useful guidelines for related future interventions in the region. We used methodology similar to those employed in related studies by (for example by Leach \& Kamangira, 1988-2001; Chromy \& Abeyesekera, 2005; Boyce \& Neale, 2006; Misturelli \& Heffernan, 2009 and Nirosha \& Broekel 2016) to generate the knowledge and following specific objectives and research questions as given below.

\section{Goal and objectives of this study}

The goal of this study was to generate knowledge on benefits, constraints to benefits and perceived livelihoods and environment impacts of Ecosystem Alliance Project in the Albertine Rift, to guide designing and implementation of future environmental management interventions in the region and related areas.

The objective of our study was therefore to generate knowledge on level of benefits, perceived impacts on livelihoods and environment of the beneficiaries, and, the factors that influenced benefit from the EA interventions among, Uganda's Albertine Rift Communities.

\section{Specific objectives of this study were:}

To determine the level of benefit from Ecosystem Alliance Project interventions among beneficiaries in Hoima, Buliisa and Kasese Districts in Uganda.

To establish impacts the Ecosystems Alliance Project had on livelihoods and environment of the beneficiaries in Hoima, Buliisa and Kasese Districts in Uganda.

To assess the constraints that may have affected level of benefit from the Ecosystem Alliance Project, among communities targeted in Hoima, Buliisa and Kasese.

\section{Materials and Methods}

Uganda Wildlife Society (UWS), AFIEGO and NAPE promoted the EA inter- 
ventions that included, awareness raising, strategies for local communities and community based organizations' participation in National REDD processes, building civil society alliances/networks/linkages for advocacy and policy influence for natural resource management, tree planting, access to resources from protected areas, bee keeping, standard fishing gears, use of hey for livestock feeding, community participation in monitoring oil companies' compliance to set environmental standards and corporate social responsibility decision making, advocacy for proper natural resource laws/practice with parliamentarians and local governments, communities' use of cages as shelter from crocodiles, Lake bank restoration and water points for livestock to the targeted beneficiaries in Uganda's Albertine Rift districts of Buliisa (located between latitudes $1^{\circ} 23^{\prime}$ and $2^{\circ} 21^{\prime}$ North, $31^{\circ} 24^{\prime}$ and $33^{\circ} 24^{\prime}$ East), Hoima $\left(01^{\circ} 25^{\prime} 55^{\prime \prime} \mathrm{N}\right.$ and $\left.31^{\circ} 21^{\prime} 09^{\prime \prime E}\right)$ and Kasese $\left(0^{\circ} 11^{\prime} 0^{\prime \prime} \mathrm{N}\right.$ and $\left.30^{\circ} 5^{\prime} 0^{\prime \prime} \mathrm{E}\right)$, for four years between 2012-2016.

At the end of the project we used a predesigned questionnaire to get data on level of benefit, factors underpinning and perceived livelihoods and environmental impacts of the interventions among beneficiaries (only those that implemented the interventions, were willing and voluntarily gave information we required were involved in the study). Additionally, key informants like government officials in charge of environment and natural resource management in the districts and, project officers in charge of the project implementation for the three NGOs in the respective districts were engaged in this study.

The number of respondents engaged per district in this study depended largely on implementation arrangement which was also dictated on by nature on environment and natural degradation problem that was being addressed in the district and on critical needs of the communities. In Kasese the project was for example more focused on impacts of mining activities (salt, minerals), fishing and human wildlife conflicts in addition to general policies and practice issues in the district. The intervention for example involved building one large cage in the Lake for all the fishing communities (who happened to be just in one settlement close by the lake) to use in fetching water from the lake to avoid crocodile attacks. Lake bank restoration in Kasese for example also involved one Lake, Katwe where, settlement and activities of the salt miners were causing negative impact on the ecosystem and the immediate effect of the restoration could be answered on by only the community (one resource user group that was settled there, in addition to opinion from the district technical officials). In Hoima the project focused more policy issues, oil exploration impacts and livelihoods. In Buliisa the focus was more on environment/natural/environment degradation that was being occasioned by poor farming, fishing and oil exploration activities, human wildlife conflicts and general policy issues.

In general, whereas all problems targeted were about environment and natural resource degradation, the interventions implementation arrangement depended on the settlement partners of the people in the districts. In Kasese the communities engaged were mainly salt miners in the Lake Katwe, the fishing communities 
in Lake George and therefore main intervention included cages for protection from crocodiles, river/Lake banks restoration, advocacy at the district level for policy issues and building civil society alliances and other interventions based on environment management capacity building needs of the people including on issues of REDD. In Hoima, policy/advocacy for appropriate practices on oil exploration activities, livelihood needs of communities and capacity building on environment management needs for focused on, with interventions such as bee keeping, policy dialogues, building civil society alliance, tree planting pursued and all the other interventions based on need of the people. In Buliisa, interventions pursued based on the environment and natural resource degradation problems, the livelihood needs of the people, impacts of oil exploration activities and policy issues, in addition to all the other interventions based on the needs of the people. In Buliisa thus, the communities involved in the project included the fisher folk in the Lake Albert, Wildlife resource dependent communities around Budongo Forest, Murchison Falls National Park and Bugungu Wildlife Reserve and Communities affected by the Oil exploration activities, crop farmers and pastoralists all over the district with interventions including, standard fishing gears, tree planting, building civil society alliances, cages for protection from crocodiles, use of hey and centralized watering points for livestock, REDD and policy dialogues among others.

The EA interventions promoted were thus the same package of environment management interventions among communities in all the three districts while on ground, the implementers made more resource investments in their location suited and community welcomed interventions. Additionally, the communities (targeted beneficiaries) tended to be in one area based on their resource use group for example miners, fisher folk, crop farmers, wildlife resource dependants, employees etc. Because of this variation, respondents involved in the study were more of representatives of their unique communities that welcomed and adopted given specific interventions among the many promoted. And therefore, a specific proportion of the total population of the community was not necessary but rather respondent selection criteria and field judgment of the authors during data collection was more important.

Given the background above, in determining sample size therefore, we were keen on the number (sample size) after which, subsequent new respondents were repeating responses previous ones had given for the same questions. This is a participatory rural approach widely used in studies like this one. According to Boyce and Neale (2006), in sampling where individual interviews are employed, large enough/representative sample can be said to be reached when in interviews, new respondents begin to repeat same stories, themes, issues and topics already captured from the earlier participants. Consequently, adopting Boyce and Neale approach, in data collection we made sure, all the different community groups were represented, district officials in charge of issues pursued additionally consulted for more perceptions and, exhaustive data captured from the 
respondents on the issues pursued in the study i.e. their perceptions on benefits, constraints to benefits and, impacts the EA interventions may have had on their environment and livelihoods. Additionally, individual interviews and use of key informant/expert views are among other approaches that have been found to generate useful information in studies like this, to inform policy and practice (Leach \& Kamangira, 1988-2001; Misturelli \& Heffernan, 2009).

In this study of the EA interventions benefits, constraints and perceive impacts among the targeted communities in the Albertine Rift in Uganda, the questions asked to obtain the data that were required were as follows: 1) Did you benefit/are you benefiting from any of these EA project interventions promoted in your district? 2) If you benefited and/or you are benefiting, which of these project interventions did you benefit from and/or are you benefiting from and how have they benefited you and or impacted on your livelihood and environment? 3) If you didn't benefit or you're not benefiting, what prevented/has prevented you? And for these, we obtained data from 12, 15 and 29 (in total 56) respondents from Kasese, Hoima, Buliisa though $\geq 300$ households benefited from interventions.

For this data that did not have same number of samples from the three districts but ensured exhaustive information capturing based on sample size criteria by Boyce and Neals (2006), in analysis we equally considered approaches that allow for analysis of data without weighting or with unequal weights, made possible with correlation analysis/models that generate relationships between dependent variable and independent explanatory variables as proposed by Chromy and Abeyasekera (2005). Therefore, using SPSS version 16 (Bryman \& Cramer, 2009), we generated percentages (\%) and correlations with relationships being considered significant when $P \leq 0.05$, for the observations under comparison and these were made for, beneficiaries' benefits, perceived factors underpinning and livelihoods and environmental impacts of the interventions. The results are presented in the section following in this paper.

\section{Results}

EA project interventions study respondent' socioeconomic characteristics Overall, 56 respondents participated in the study of which, 29/56 (51.8\%) were from Buliisa, 15/56 (26.8\%) were from Hoima and the rest i.e. 12/56 (21.4\%) were from Kasese district (Table 1). Out of the total 56 respondents who were involved in this study, $80.4 \%$ were males and $19.60 \%$ were females (Table 1 ). Majority (37.50\%) of the 56 respondents involved in this study were aged $31-40$ years old and, majority (62.5\%) of the 56 respondents lived in families of more than 6 members in household (Table 1). In education, majority $(32.10 \%)$ of the 56 respondents who participated in this study has attained secondary level education while in occupation, $27 / 56(48.20 \%)$ were crop farmers (Table 1). More detailed socioeconomic characteristics of the 56 respondents engaged in this study are in Table 1 below. 
Table 1. Socioeconomic characteristics of respondents in the study of benefits and underpinning factors among Albertine Rift Uganda beneficiaries of EA Project interventions $(\mathrm{N}=56)$.

\begin{tabular}{|c|c|c|}
\hline $\begin{array}{l}\text { Respondent's socioeconomic } \\
\text { characteristic }\end{array}$ & $\begin{array}{l}\text { Frequency }(\mathrm{N}) \text { of respondents under the } \\
\text { given socioeconomic category }\end{array}$ & $\begin{array}{l}\text { Percentage (\%) of respondents under the } \\
\text { given socioeconomic category }\end{array}$ \\
\hline \multicolumn{3}{|l|}{ District } \\
\hline Kasese & 12 & 21.40 \\
\hline Hoima & 15 & 26.80 \\
\hline Buliisa & 29 & 51.80 \\
\hline \multicolumn{3}{|l|}{ Sex } \\
\hline Male & 45 & 80.40 \\
\hline Female & 11 & 19.60 \\
\hline \multicolumn{3}{|l|}{ Age } \\
\hline$<18-30 \mathrm{yrs}$ & 10 & 17.90 \\
\hline $31-40 \mathrm{yrs}$ & 21 & 37.50 \\
\hline $41-50$ yrs & 14 & 25.00 \\
\hline $51-60 \mathrm{yrs}$ & 04 & 07.10 \\
\hline $61-70 \mathrm{yrs}$ & 06 & 10.70 \\
\hline$>70 \mathrm{yrs}$ & 01 & 01.80 \\
\hline \multicolumn{3}{|l|}{ Education level } \\
\hline None & 02 & 3.60 \\
\hline Primary & 12 & 21.40 \\
\hline Secondary & 18 & 32.10 \\
\hline Tertiary & 09 & 16.10 \\
\hline Degree & 07 & 12.50 \\
\hline Didn't respond on education & 08 & 14.30 \\
\hline \multicolumn{3}{|l|}{ Respondent's family size } \\
\hline $1-3$ individuals & 04 & 07.10 \\
\hline $4-6$ individuals & 16 & 28.60 \\
\hline$>6$ individuals & 35 & 62.50 \\
\hline Didn't respond on family size & 01 & 01.80 \\
\hline \multicolumn{3}{|l|}{ Respondent's marital status } \\
\hline Single & 03 & 5.40 \\
\hline Married & 44 & 78.60 \\
\hline Widowed & 01 & 01.80 \\
\hline Didn't respond on marriage & 08 & 14.30 \\
\hline \multicolumn{3}{|l|}{ Respondent's occupation } \\
\hline Crop farmer & 27 & 48.20 \\
\hline Fisher folk & 06 & 10.70 \\
\hline Pastoralist & 03 & 05.40 \\
\hline
\end{tabular}




\section{Continued}

Wildlife resource dependant

Employee

Didn't respond on occupation

Respondent's land tenure

Freehold

Leasehold

Customary

Communal

Didn't respond on land tenure

Respondent's land size

$<1$ ha
$1-3$ ha
$4-7$ ha
$>7$ ha

Didn't respond on land size

\section{5}

11

04

01

09

14

04

28

02

13

02

14

25
08.90

19.60

07.10

01.80

16.10

25.00

07.10

50.00

03.60

23.20

03.60

25.00

44.60

\section{Level of benefit from EA project interventions among respondents}

Benefit from EA interventions was high in all the three districts; within districts, 11 out of the 12 respondents (91.70\%) from Kasese said they had benefits from EA interventions (i.e. only one person among the respondents did not benefit from the project). In Hoima district, all the 15 respondents (100\%) who reported they had benefited from the EA interventions. In, Buliisa, 27/29 (93.10\%) said they benefited from the EA interventions and only two individuals among the respondents said they did not benefit. All the 11 women who participated as respondents in this study said they benefited from the project while, 42 out of the 45 men (93.30\%) involved reported benefiting from the EA interventions.

Categorized by their occupation; all the 27 crop farmers (100\%) who were involved in this study said they benefited from the EA interventions, all the 6 fisher folk (100\%) who were involved in this study said they had benefited from the interventions, all the pastoralist (3) who were involved said they had benefited while 3 out of the $4(80 \%)$ of the wildlife resource dependent respondents who were involved in this study said they benefited from the project and 10 out of 11 (90/90\%) employees involved in the study acknowledged they benefited from the project.

Out of the 56 respondents, only 2 were not educated at all and both of them reported benefiting from the EA interventions, 12 out of the 56 respondents had attained primary education and all of them (100\%) reported benefiting from EA interventions, 18/56 respondent had secondary level education and, 17 of these (94.40\%) reported benefiting from EA interventions, 9 respondents of 56 had attained tertiary level education and all these (100\%) said they benefited from EA interventions while, 7/56 respondents had degrees and, $5(71.4 \%)$ of these 
reported benefiting from EA interventions. Other variations in level of benefit from EA interventions, with respondents' socioeconomic characteristics are given in Table 2 below.

Table 2. Respondent's benefit from EA Project interventions in Albertine Rift, Uganda $(\mathrm{N}=56)$.

\begin{tabular}{|c|c|c|c|c|}
\hline $\begin{array}{l}\text { Respondents socio-economic } \\
\text { characteristics }\end{array}$ & $\begin{array}{l}\text { Statistical } \\
\text { variability }\end{array}$ & $\begin{array}{l}\text { Respondents benefitted } \\
\text { from EA interventions }\end{array}$ & $\begin{array}{l}\text { Respondents didn't benefit } \\
\text { from EA interventions }\end{array}$ & Total \\
\hline \multicolumn{5}{|l|}{ Family size } \\
\hline \multirow{2}{*}{1 - 3 individuals } & Count & 03 & 01 & 04 \\
\hline & $\%$ & 75.00 & 25.00 & 100 \\
\hline \multirow{2}{*}{4 - 6 individuals } & Count & 14 & 02 & 16 \\
\hline & $\%$ & 87.50 & 12.50 & 100 \\
\hline \multirow{2}{*}{$>6$ individuals } & Count & 35 & 00 & 35 \\
\hline & $\%$ & 100.00 & 00.00 & 100 \\
\hline \multicolumn{5}{|l|}{ Marital status } \\
\hline \multirow{2}{*}{ Single } & Count & 03 & 00 & 03 \\
\hline & $\%$ & 100.00 & 00.00 & 100 \\
\hline \multirow{2}{*}{ Married } & Count & 42 & 02 & 44 \\
\hline & $\%$ & 95.50 & 04.50 & 100 \\
\hline \multirow{2}{*}{ Widowed } & Count & 01 & 00 & 01 \\
\hline & $\%$ & 100.00 & 00.00 & 100 \\
\hline \multicolumn{5}{|l|}{ Land Tenure } \\
\hline \multirow{2}{*}{ Freehold } & Count & 01 & 00 & 01 \\
\hline & $\%$ & 100.00 & 00.00 & 100 \\
\hline \multirow{2}{*}{ Leasehold } & Count & 09 & 00 & 09 \\
\hline & $\%$ & 100.00 & 00.00 & 100 \\
\hline \multirow{2}{*}{ Customary } & Count & 13 & 01 & 14 \\
\hline & $\%$ & 92.90 & 07.10 & 100 \\
\hline \multirow{2}{*}{ Communal } & Count & 04 & 00 & 04 \\
\hline & $\%$ & 100.00 & 00.00 & 100 \\
\hline \multicolumn{5}{|l|}{ Size of land } \\
\hline \multirow{2}{*}{$<1$ ha } & Count & 02 & 00 & 02 \\
\hline & $\%$ & 100.00 & 00.00 & 100 \\
\hline \multirow{2}{*}{$1-3 \mathrm{ha}$} & Count & 12 & 01 & 13 \\
\hline & $\%$ & 92.30 & 07.70 & 100 \\
\hline \multirow{2}{*}{$4-7 \mathrm{ha}$} & Count & 02 & 00 & 02 \\
\hline & $\%$ & 100.00 & 00.00 & 100 \\
\hline \multirow{2}{*}{$>7$ ha } & Count & 14 & 00 & 14 \\
\hline & $\%$ & 100.00 & 00.00 & 100 \\
\hline
\end{tabular}


Factors that constrained respondents benefiting from EA project interventions

None of the respondents from Kasese reported any constraints to receive benefits from the EA interventions. In Hoima out of the 15 respondents who were involved in the study, 11 responded to the question on constraints and of these, $20 \%$ said climatic conditions, limited technical capacity curtailed them from benefiting and $33.30 \%$ said the project did not meet their expectations. In Buliisa, 13 respondents out of the 29 who were involved in this study responded to the question on constraints and of these, $10.30 \%$ said climatic conditions and limited technical capacity to manage the interventions curtailed their benefit from EA interventions, $10.30 \%$ said the interventions were not a priority to them and or they had no technical capacity to manage them, $17.20 \%$ said they did not about the intervention in time, $2.40 \%$ said the interventions were not supplied to all people, while, $06.90 \%$ said the interventions were below their expectations.

By sex, out of the 45 men who participated in this study, 19 responded to the question on constraints to benefit from EA and of the 19, one said the intervention was not supplied to all people, 5 said they did not know the time of interventions, 4 said climatic conditions and time of intervention limited them, another 4 said the intervention was not their priority and they had no technical capacity for management while for another 5 , the interventions were below their expectations. Similarly, out of the 11 women involved in the study, 6 responded to the question on constraints to benefit and of these, 2 said climatic conditions/intervention time limited them, 2 said the intervention was not priority and they had limited technical capacity to manage them while, for another 2 , the interventions were below their expectations.

By education level, one of the two respondents who had not attained any education said climatic conditions/time of intervention limited their benefits from EA Interventions, one from those who had attained primary level education and, three who had attained secondary level education mentioned the same while this was not a constraint mentioned among those with degrees and tertiary level of education. two from respondents from primary level education category and two from those with degrees stated they did not know about the interventions, one responded with a degree stated the interventions were not supplied to all while, two respondents each from the category primary, secondary and tertiary level education said the interventions were not their priority and they had limited technical capacity for management, three respondents from primary, one from secondary and two from tertiary level education category said the interventions were below their priority.

By landholding size, intervention not supplied to all, respondent not knowing about intervention were not mentioned at all as factors that limited constraint to EA interventions, for respondents with less than one hectare of land, climatic conditions, intervention not being priority/limited management technical ca- 
pacity and intervention being below expectation did not come out as constraints to benefit while they were to some people with more than one hectare of land, mentioned by at least 1 to 4 individuals in the land holding size category $1-3$ hectares (at least 1 respondent for all the three constraints), the same with $4-7$ hectares (ha) and, 1, 2, 4 respectively for the three constraints, for respondents with landholding size greater than $7 \mathrm{ha}$ ). Report on constraints to benefit from EA interventions varied with other socioeconomic characteristics of respondents as shown in Table 3 below.

Table 3. Albertine Rift Uganda EA project intervention benefits-respondents' constrains $(\mathrm{N}=56)$.

\begin{tabular}{|c|c|c|c|c|c|c|}
\hline $\begin{array}{l}\text { Respondents } \\
\text { socio-economic } \\
\text { characteristics }\end{array}$ & $\begin{array}{l}\text { Statistical } \\
\text { variability }\end{array}$ & $\begin{array}{l}\text { Interventions } \\
\text { not supplied to } \\
\text { all }\end{array}$ & $\begin{array}{l}\text { Respondent didn't } \\
\text { know in time of } \\
\text { interventions }\end{array}$ & $\begin{array}{c}\text { Climatic conditions/ } \\
\text { intervention time } \\
\text { limited }\end{array}$ & $\begin{array}{l}\text { intervention not respondent } \\
\text { priority limited t technical } \\
\text { capacity }\end{array}$ & $\begin{array}{c}\text { Intervention } \\
\text { below } \\
\text { expectation }\end{array}$ \\
\hline \multicolumn{7}{|l|}{ Age } \\
\hline \multirow{2}{*}{$<18-30$ yrs } & Count & 01 & 02 & 00 & 01 & 02 \\
\hline & $\%$ & 10.00 & 20.00 & 00.00 & 10.00 & 20.00 \\
\hline \multirow{2}{*}{$31-40$ yrs } & Count & 00 & 01 & 03 & 01 & 00 \\
\hline & $\%$ & 00.00 & 4.80 & 14.30 & 04.80 & 00.00 \\
\hline \multirow{2}{*}{$41-50 \mathrm{yrs}$} & Count & 00 & 01 & 02 & 02 & 01 \\
\hline & $\%$ & 00.00 & 07.10 & 14.30 & 14.30 & 07.10 \\
\hline \multirow{2}{*}{$51-60$ yrs } & Count & 00 & 01 & 01 & 00 & 00 \\
\hline & $\%$ & 00.00 & 25.00 & 25.00 & 00.00 & 00.00 \\
\hline \multirow{2}{*}{$61-70$ yrs } & Count & 00 & 00 & 00 & 02 & 03 \\
\hline & $\%$ & 00.00 & 00.00 & 00.00 & 33.30 & 50.00 \\
\hline \multirow{2}{*}{$>70 \mathrm{yrs}$} & Count & 00 & 00 & 00 & 00 & 01 \\
\hline & $\%$ & 00.00 & 00.00 & 00.00 & 00.00 & 100.00 \\
\hline \multicolumn{7}{|l|}{ Family size } \\
\hline \multirow{2}{*}{$1-3$ individuals } & Count & 00 & 00 & 00 & 01 & 00 \\
\hline & $\%$ & 00.00 & 00.00 & 00.00 & 25.00 & 00.00 \\
\hline \multirow{2}{*}{$4-6$ individuals } & Count & 01 & 02 & 00 & 00 & 01 \\
\hline & $\%$ & 06.20 & 12.50 & 00.00 & 00.00 & 06.20 \\
\hline \multirow{2}{*}{$>6$ individuals } & Count & 00 & 03 & 06 & 05 & 06 \\
\hline & $\%$ & 00.00 & 08.60 & 17.10 & 14.30 & 17.10 \\
\hline \multicolumn{7}{|l|}{ Marital status } \\
\hline \multirow{2}{*}{ Single } & Count & 00 & 01 & 00 & 00 & 00 \\
\hline & $\%$ & 00.00 & 33.30 & 00.00 & 00.00 & 00.00 \\
\hline \multirow{2}{*}{ Married } & Count & 00 & 04 & 05 & 05 & 07 \\
\hline & $\%$ & 00.00 & 09.10 & 11.40 & 11.40 & 15.90 \\
\hline \multirow{2}{*}{ Widowed } & Count & 00 & 00 & 00 & 00 & 00 \\
\hline & $\%$ & 00.00 & 00.00 & 00.00 & 00.00 & 00.00 \\
\hline
\end{tabular}




\section{Continued}

\begin{tabular}{|c|c|c|c|c|c|c|}
\hline Occupation & & & & & & \\
\hline \multirow{2}{*}{ Crop farmer } & Count & 00 & 03 & 05 & 04 & 04 \\
\hline & $\%$ & 00.00 & 11.10 & 18.50 & 14.80 & 14.80 \\
\hline \multirow{2}{*}{ Fisher folk } & Count & 00 & 00 & 01 & 00 & 00 \\
\hline & $\%$ & 00.00 & 00.00 & 16.70 & 00.00 & 00.00 \\
\hline \multirow{2}{*}{ Pastoralist } & Count & 00 & 01 & 00 & 01 & 00 \\
\hline & $\%$ & 00.00 & 33.30 & 00.00 & 33.30 & 00.00 \\
\hline \multirow{2}{*}{$\begin{array}{l}\text { Wildlife resource } \\
\text { dependent }\end{array}$} & Count & 01 & 00 & 00 & 00 & 01 \\
\hline & $\%$ & 20.00 & 00.00 & 00.00 & 00.00 & 20.00 \\
\hline \multirow{2}{*}{ Employee } & Count & 00 & 01 & 00 & 01 & 01 \\
\hline & $\%$ & 00.00 & 09.10 & 00.00 & 09.10 & 09.10 \\
\hline \multicolumn{7}{|l|}{ Land Tenure } \\
\hline \multirow{2}{*}{ Freehold } & Count & 00 & 00 & 00 & 00 & 00 \\
\hline & $\%$ & 00.00 & 00.00 & 00.00 & 00.00 & 00.00 \\
\hline \multirow{2}{*}{ Leasehold } & Count & 00 & 00 & 00 & 00 & 00 \\
\hline & $\%$ & 00.00 & 00.00 & 00.00 & 00.00 & 00.00 \\
\hline \multirow{2}{*}{ Customary } & Count & 00 & 00 & 02 & 01 & 02 \\
\hline & $\%$ & 00.00 & 00.00 & 14.30 & 07.10 & 14.30 \\
\hline \multirow{2}{*}{ Communal } & Count & 01 & 01 & 01 & 01 & 00 \\
\hline & $\%$ & 25.00 & 25.00 & 25.00 & 25.00 & 00.00 \\
\hline
\end{tabular}

Correlations, benefit from EA Interventions and, beneficiary socioeconomic characteristic

Benefit from tree planting, Standard fishing gears, REDD, Use hey for livestock feeding (sustainable livestock management), and advocacy for sustainable natural resources laws and policies did not have relationship with any of the respondents socioeconomic characteristics investigated i.e. district, sex, education level, family size, marital status, occupation, land tenure and land holding size ( $p \geq 0.05$ for all these cases, Table 4 ).

Building civil Society alliances related with sex of the beneficiary $(p=0.00$, and was especially important among females), community participation in monitoring compliance of mining companies to environmental standards had relationship with the beneficiaries' occupation ( $p=0.03$, being important among employees) and, use of cages as shelter from crocodiles related with district (especially important in Kasese), family size (being important among families of 4 6 individuals in a household) and, occupation (being important among wildlife/wetlands resource dependent communities) while benefit from bee keeping related with the beneficiaries' sex (being important for females), $p \leq 0.05$, for all these cases (Table 4). Detailed results on percentage variation of respondent socioeconomic characteristic with benefit from intervention are not presented here due volume of results output tables but can be availed on request). 
Table 4. Benefit from Albertine Rift Uganda EA interventions, correlations with respondent socioeconomic correlations $(\mathrm{N}=56)$.

\begin{tabular}{|c|c|c|c|c|c|c|c|c|c|c|}
\hline $\begin{array}{c}\text { Variables } \\
\text { (interventions } \\
\text { benefited from) }\end{array}$ & $\begin{array}{c}\text { Statistical measure } \\
\text { of variability }\end{array}$ & District & Sex & Age & $\begin{array}{l}\text { Education } \\
\text { level }\end{array}$ & $\begin{array}{l}\text { Family } \\
\text { size }\end{array}$ & $\begin{array}{l}\text { Marital } \\
\text { status }\end{array}$ & Occupation & $\begin{array}{l}\text { Land } \\
\text { tenure }\end{array}$ & Landsize \\
\hline \multirow{2}{*}{ REDD } & Pearson Correlation & -0.16 & -0.08 & -0.08 & -0.04 & -0.22 & 0.02 & 0.07 & -0.19 & -0.11 \\
\hline & Sig. (2-tailed) & 0.25 & 0.57 & 0.57 & 0.75 & 0.09 & 0.89 & 0.61 & 0.14 & 0.40 \\
\hline \multirow{2}{*}{$\begin{array}{c}\text { Building civil } \\
\text { society alliances }\end{array}$} & Pearson Correlation & 0.14 & $-0.38^{\star *}$ & 0.02 & -0.04 & -0.16 & 0.02 & -0.19 & -0.05 & -0.02 \\
\hline & Sig. (2-tailed) & 0.29 & 0.00 & 0.87 & 0.75 & 0.25 & 0.88 & 0.16 & 0.73 & 0.89 \\
\hline \multirow{2}{*}{ Tree planting } & Pearson Correlation & 0.12 & -0.21 & 0.01 & 0.07 & -0.09 & 0.05 & 0.17 & 0.23 & -0.04 \\
\hline & Sig. (2-tailed) & 0.44 & 0.12 & 0.95 & 0.62 & 0.52 & 0.71 & 0.21 & 0.09 & 0.75 \\
\hline \multirow{2}{*}{$\begin{array}{c}\text { Standard } \\
\text { fishing gears }\end{array}$} & Pearson Correlation & -0.17 & 0.09 & 0.09 & -0.04 & 0.03 & 0.07 & -0.09 & 0.09 & -0.09 \\
\hline & Sig. (2-tailed) & 0.22 & 0.49 & 0.49 & 0.79 & 0.85 & 0.60 & 0.50 & 0.53 & 0.48 \\
\hline \multirow{2}{*}{$\begin{array}{l}\text { Sustainable livestock } \\
\text { management }\end{array}$} & Pearson Correlation & -0.26 & -0.02 & 0.09 & 0.13 & -0.14 & 0.10 & 0.17 & -0.12 & -0.22 \\
\hline & Sig. (2-tailed) & 0.06 & 0.90 & 0.53 & 0.33 & 0.30 & 0.45 & 0.21 & 0.37 & 0.10 \\
\hline \multirow{2}{*}{$\begin{array}{l}\text { Community } \\
\text { participation } \\
\text { in monitoring }\end{array}$} & Pearson Correlation & -0.07 & -0.24 & 0.09 & 0.08 & -0.08 & 0.12 & $.29^{*}$ & -0.01 & 0.00 \\
\hline & Sig. (2-tailed) & 0.59 & 0.08 & 0.52 & 0.56 & 0.55 & 0.39 & 0.03 & 0.93 & 0.98 \\
\hline \multirow{2}{*}{$\begin{array}{l}\text { Advocacy for proper } \\
\text { natural resource law }\end{array}$} & Pearson Correlation & -0.06 & -0.22 & 0.02 & -0.11 & -0.09 & 0.02 & -0.01 & 0.22 & 0.12 \\
\hline & Sig. (2-tailed) & 0.64 & 0.09 & 0.88 & 0.40 & 0.47 & 0.87 & 0.92 & 0.09 & 0.39 \\
\hline \multirow{2}{*}{$\begin{array}{l}\text { Cages as shelter from } \\
\text { crocodiles }\end{array}$} & Pearson Correlation & $0.53^{\star *}$ & -0.08 & 0.12 & 0.01 & $0.31^{*}$ & -0.01 & $-0.42^{\star *}$ & -0.08 & 0.02 \\
\hline & Sig. (2-tailed) & 0.00 & 0.56 & 0.39 & 0.93 & 0.02 & 0.94 & 0.00 & 0.56 & 0.88 \\
\hline \multirow{2}{*}{ Bee keeping } & Pearson Correlation & -0.1 & $-0.31^{\star}$ & -0.05 & 0.08 & -0.18 & 0.15 & -0.11 & 0.02 & 0.03 \\
\hline & Sig. (2-tailed) & 0.462 & 0.02 & 0.74 & 0.57 & 0.185 & 0.268 & 0.418 & 0.89 & 0.838 \\
\hline
\end{tabular}

Table note: ${ }^{*}$. Correlation is significant at the 0.05 level (2-tailed). ${ }^{* *}$. Correlation is significant at the 0.01 level (2-tailed).

Correlations, perceptions on impacts of EA Interventions and, beneficiary socioeconomic characteristic

Perception that EA interventions improved household income had relationship with the level of education of the beneficiary, $(p=0.01$, was especially important for the beneficiaries who were not educated at all), perception that the interventions reduced conflicts with wildlife related with the beneficiary's family size ( $p=0.02$ and was especially important for households with $4-6$ members as their family size) and occupation ( $p=0.00$, being important especially for crop farmers) (Table 5).

Perception that interventions enhanced capacity for environmental management related with the beneficiaries' sex ( $p=0.05$, especially important for females) and $p=0.02$ with family size, being important for the households having 4 - 6 members as family size (Table 5). Detailed results on percentage variation of socioeconomic characteristic with perception on intervention impacts not presented here due to large results tables can be availed on request).

Correlations, perceptions on constraints to benefit from EA Interventions and, beneficiary socioeconomic characteristic

Perception that information about intervention did not reach beneficiary in time limiting benefit related with the district (was important especially in Hoima 
Buliisa, $p=0.04$ ), Table 6).

Perception that time of intervention and climatic conditions limited benefit related with the beneficiaries' occupation ( $p=0.04$ being important among crop farmers) while perception that intervention did not meet expectations and or was not a priority of the beneficiary related with age, being important $(p=0.01)$ among the age group 18 to 30 and $61-70$ years (Table 6). Detailed results on percentage variation of respondent socioeconomic characteristic with their perception on constraints to benefit from the EA intervention are not presented here due to volume of results output tables but can be availed upon request).

Table 5. Correlations, perception on impacts of the Albertine Rift Uganda EA interventions with, respondent socioeconomic correlations $(\mathrm{N}=56)$.

\begin{tabular}{ccccccccccc}
\hline Variables & $\begin{array}{c}\text { Statistical measure } \\
\text { of variability }\end{array}$ & District & Sex & Age $\begin{array}{c}\text { Education } \\
\text { level }\end{array}$ & $\begin{array}{c}\text { Family } \\
\text { size }\end{array}$ & $\begin{array}{c}\text { Marital } \\
\text { status }\end{array}$ & Occupation & $\begin{array}{c}\text { Land } \\
\text { tenure }\end{array}$ & Landsize \\
\hline $\begin{array}{c}\text { Intervention impact } \\
\text { led to sustainable }\end{array}$ & Pearson Correlation & -0.19 & -0.06 & -0.19 & -0.06 & -0.12 & -0.03 & 0.19 & -0.02 & 0.07 \\
$\begin{array}{c}\text { land/water resources } \\
\text { management }\end{array}$ & Sig. (2-tailed) & 0.15 & 0.65 & 0.16 & 0.67 & 0.40 & 0.82 & 0.15 & 0.91 & 0.61 \\
$\begin{array}{c}\text { improved household } \\
\text { income }\end{array}$ & $\begin{array}{c}\text { Pearson Correlation } \\
\begin{array}{c}\text { reduced human } \\
\text { wildlife conflicts }\end{array}\end{array}$ & -0.11 & 0.12 & 0.11 & $0.34^{*}$ & -0.15 & 0.09 & 0.21 & 0.11 & -0.15 \\
$\begin{array}{c}\text { Searson (2-tailed) } \\
\text { enhanced capacity } \\
\text { for environmental } \\
\text { management }\end{array}$ & Sig. (2-tailed) & 0.43 & 0.39 & 0.40 & 0.01 & 0.27 & 0.52 & 0.12 & 0.43 & 0.27 \\
\hline
\end{tabular}

Table note: ${ }^{*}$. Correlation is significant at the 0.05 level (2-tailed). ${ }^{* *}$. Correlation is significant at the 0.01 level (2-tailed).

Table 6. Correlations, perception on benefit from Albertine Rift Uganda EA interventions constraints with, respondent socioeconomic characteristics $(\mathrm{N}=56)$.

\begin{tabular}{|c|c|c|c|c|c|c|c|c|c|c|}
\hline Variables & $\begin{array}{c}\text { Statistical measure of } \\
\text { variability }\end{array}$ & District & Sex & Age & $\begin{array}{c}\text { Education } \\
\text { level }\end{array}$ & $\begin{array}{l}\text { Family } \\
\text { size }\end{array}$ & $\begin{array}{l}\text { Marital } \\
\text { status }\end{array}$ & Occupation & $\begin{array}{l}\text { Land } \\
\text { tenure }\end{array}$ & Landsize \\
\hline \multicolumn{11}{|l|}{ Benefit Constrains } \\
\hline \multirow{2}{*}{$\begin{array}{l}\text { not supplied to } \\
\text { all beneficiaries }\end{array}$} & Pearson Correlation & -0.12 & 0.07 & 0.17 & -0.11 & 0.12 & $-0.31^{*}$ & -0.1 & -0.11 & -0.12 \\
\hline & Sig. (2-tailed) & 0.39 & 0.63 & 0.21 & 0.44 & 0.37 & 0.02 & 0.46 & 0.40 & 0.38 \\
\hline \multirow{2}{*}{$\begin{array}{l}\text { Interventions information } \\
\text { not received in time }\end{array}$} & Pearson Correlation & $-0.27^{\star}$ & 0.16 & 0.10 & -0.09 & -0.01 & 0.17 & 0.07 & -0.22 & $-0.28^{*}$ \\
\hline & Sig. (2-tailed) & 0.04 & 0.26 & 0.46 & 0.49 & 0.97 & 0.21 & 0.59 & 0.09 & 0.04 \\
\hline \multirow{2}{*}{$\begin{array}{c}\text { Climate/ time of } \\
\text { intervention limited } \\
\text { beneficiary }\end{array}$} & Pearson Correlation & -0.09 & -0.12 & -0.02 & 0.11 & -0.22 & -0.03 & $0.27^{\star}$ & -0.11 & -0.04 \\
\hline & Sig. (2-tailed) & 0.53 & 0.38 & 0.91 & 0.42 & 0.10 & 0.84 & 0.04 & 0.44 & 0.76 \\
\hline \multirow{2}{*}{$\begin{array}{c}\text { Not priority/no } \\
\text { management technical } \\
\text { capacity }\end{array}$} & Pearson Correlation & -0.09 & -0.12 & -0.15 & 0.14 & -0.04 & -0.03 & 0.12 & -0.18 & 0.00 \\
\hline & Sig. (2-tailed) & 0.53 & 0.38 & 0.26 & 0.29 & 0.76 & 0.84 & 0.39 & 0.18 & 0.99 \\
\hline \multirow{2}{*}{$\begin{array}{l}\text { Intervention didn't meet } \\
\text { expectation }\end{array}$} & Pearson Correlation & 0.01 & -0.09 & $-0.33^{*}$ & 0.06 & -0.16 & 0.14 & -0.02 & -0.18 & 0.04 \\
\hline & Sig. (2-tailed) & 0.95 & 0.53 & 0.01 & 0.66 & 0.25 & 0.31 & 0.89 & 0.19 & 0.79 \\
\hline
\end{tabular}

Table note: ${ }^{*}$. Correlation is significant at the 0.05 level (2-tailed). ${ }^{* *}$. Correlation is significant at the 0.01 level (2-tailed). 


\section{Discussion}

The EA project interventions were considered beneficial mainly because it improved the Albertine Rift communities' knowledge/practice on environment management, reduced conflicts with wildlife, enhanced household income, access to resources from protected areas and participation in monitoring Oil companies' compliance to environmental standards. There were however, factors which constrained benefits, including limited technical capacity, information on interventions received late, time of intervention being not convenient, intervention not priority and or not meeting beneficiaries' expectations and unfavorable climatic conditions among others.

Our findings also show that level of benefit and or constraints experienced depended on beneficiaries socioeconomic variables as we can see from the EA interventions for example that, perception that the interventions were useful because they improved household income was especially important for the beneficiaries who were not educated, perception that the interventions were beneficial because they enhanced beneficiaries' capacity for environment management was especially important for women and for households that were relatively big i.e. composed of 4 - 6 members and, perception that the interventions was useful because they reduced the conflicts beneficiaries had with wildlife was especially important for beneficiaries who had relatively big family size (4 - 6 members in a household) and for people who depended on wetlands/wildlife resources.

Additionally, from our results, one can see that among constraints to benefit from EA interventions, time of intervention supply and climatic conditions as limiting as especially important among crop farmers while, the interventions not meeting expectation was a factor among beneficiaries who were youths (in the age group 18 - 31) and or just after middle age (in the age group 61 - 70 years old). These are some of the specific findings from our study that point to unique socioeconomic factors of beneficiaries influencing their level of benefit from and the impacts they receive from given technologies.

The EA interventions beneficiaries were also very specific in recommending factors for consideration in improvement, for future interventions to enhance their benefit and impacts on their environment and livelihoods. They among others suggested that future interventions start with studies to elucidate most appropriate interventions, involve all stakeholders from the beginning, incorporate post adoption extension services, monitoring and evaluation and ensure equitable distribution to all members of the targeted communities. Among these suggestions, the role and value of sufficient extension services and follow up monitoring and evaluation activities are compounded, much in line with the reports made by Nirosha and Broekel from their study of farmers in Sri Lanka (Nirosha \& Broekel, 2016).

Our findings provide additional knowledge in support of earlier studies which allude technology benefit to its ability to yield income/livelihood needs, suit beneficiaries' environment conditions (Buyinza et al., 2008; Tawari \& Davies, 
2009) and beneficiaries' knowledge and management technical capacity being important (Abebe, 2007; Place et al., 2020; Arikawei \& Nzeneri, 2013) and, more findings by Nirosha and Broekel (2016), in their study of farmer adoption of technologies based on perceptions of the beneficiaries and the extension officials who were involved in the project. The two for example found that, aamong factors constraining adoption, lack of resources, incompatibility and complexity of new technology, socio-economic and cultural constraints, inadequacies in extension intervention, technical training and information were important (Nirosha \& Broekel, 2016). Moreover, they said environmental and economic barriers, poor educational competencies of farmers and weak information links with the other actors of the network also constrained adoption. These are largely similar to what beneficiaries of the EA interventions in Uganda's Albertine Rift gave as factors that constrained their level of benefit from and impact of the technology on their environment and livelihoods as presented in the results and discussed here in this paper.

\section{Conclusion and Recommendation}

In conclusion, our finding shows that more than ninety percent of targeted beneficiaries in the Albertine Rift district of Buliisa, Kasese and Hoima benefited from EA project interventions and in their perception, the interventions enhanced their incomes, environment management capacity and, reduced conflicts they had with wildlife.

Despite the high level of reported benefits from EA interventions, the time of intervention and climatic conditions were limiting factors especially for, the crop farmers, while, intervention not meeting expectation was a limiting factor among the youth and the elderly. To address these constraints, the beneficiaries suggested that future initiatives start with research to determine interventions that match their environment, priority and expectations and these are distributed equitably after prior information/expectation management and technical capacity building.

Based on these, our recommendation therefore is that, for agriculture or environment management interventions, research needs to be precursor, to guide selection of interventions prior to promotion and that, promoted interventions need to match environment, be supplied after beneficiaries' prior information, expectation management and technical capacity building.

\section{Acknowledgements}

We thank Professor Joseph Obua for the technical editing of our paper and the reviewers for the journal of Geosciences and environment protection for the additional review inputs that helped us improve our article. We thank our project partners, the National Association of Professional Environmentalists (NAPE), African Institute for Energy Governance (AFIEGO), Buliisa district Local Government, Community Based Organizations and the Local Communities that 
participated in our project and in this study by providing information and field assistance during data collection. We thank IUCN National Committee of the Netherlands, Wetlands International and Both Ends (Ecosystem Alliance) funded by the Royal Dutch Government, for the financial support of the project.

\section{Conflicts of Interest}

The authors declare no conflicts of interest regarding the publication of this paper.

\section{References}

Abebe, W. (2007). Determinants of Adoption of Improved Box Hive in Atsbi Wemberta District of Eastern Zone, Tigray Region. PhD Thesis, Haramaya: Haramaya University.

Arikawei, A. R., \& Nzeneri, I. S. (2013). The Utilization of Fishing Operational Methods on Adult Learners' Economic Livelihood for Poverty Reduction in Bayelsa State. International Journal of Research in Social Sciences, 2, 56-63.

Boyce, C., \& Neale, P. (2006). Conducting In-Depth Interviews: A Guide for Designing and Conducting In-Depth Interviews for Evaluation Input. In Pathfinder International Tools Eries, Monitoring and Evaluation-2. Pathfinder International.

Bridges Trade Biores (2003). Volume 3, Number 17. International Centre for Trade and Biosafety Sustainable Development (ICTSD) Switzerland.

Bridges Trade Biores (2006). International Centre for Trade and Biosafety Sustainable Development (ICTSD) Switzerland.

Bridges Trade Biores (2007). International Centre for Trade and Biosafety Sustainable Development (ICTSD) Switzerland.

Bryman, A., \& Cramer, D. (2009). Quantitative Data Analysis with SPSS 14, 15 and 16: A Guide for Social Scientists. Hove, East Sussex, UK: Routledge.

Buyinza, M., Banana, A. Y, Nabanoga, G., \& Ntakimanye, A. (2008). Farmers' Adoption of Rotational Woodlot Technology in Kigorobya Sub-County of Hoima District, Western Uganda. Ethno Botany Research and Applications, 6, 107-115. https://doi.org/10.17348/era.6.0.107-115

Chromy, J. R., \& Abeyasekera, S. (2005). Statistical Analysis of Survey Data. In Household Sample Survey in Developing and Transition Countries, United Nations Publication ST/ESA/STAT/SER.F/96 (Chapter XIX, 388-417).

Giannakas, K., \& Fulton, M. (2000). Consumption Effects of Genetic Modifications: What If Consumers Are Right? EPTD Discussion Paper No. 69, USA: Food Policy Research Institute.

Kugonza, A., Buyinza, M., \& Byakagaba, P. (2009). Linking Local Communities' Livelihoods and Forest Conservation in Masindi District, North Western Uganda. Research Journal of Applied Sciences, 4, 10-16.

Leach, M., \& Kamangira, J. (1988-2001). Shotgun Wedding or Happy Marriage? Integrating PRA and Sample Surveys in Malawi. Participatory Learning and Action (PLA) notes CD-ROM, International Institute for Environment and Development (IIED).

Misturelli, F., \& Heffernan, C. (2009). An Analysis of Advantages and Limitations of PRA Tools in Livestock Research. In F. Misturelli, \& C. Heffernan (Eds.), An Analysis of Advantages and Limitations of PRA Tools in Livestock Research.

Nirosha, S., \& Broekel, T. (2016). Factors Constraining Farmers' Adoption of New Agricultural Technology Programme in Hambantota District in Sri Lanka: Perceptions of 
Agriculture Extension Officers. 13th International Conference on Business Management (ICBM), University of Sri Jayewardenepura, Sri Lanka.

https://ssrn.com/abstract=2910350

Oloo, J. O. (2013). Influence of Traditions/Customs and Beliefs/Norms on Women in Tree Growing in Siaya County, Kenya. Global Journal of Environmental Science and Technology, 1, 1-0.

Place, F., Ajayi, O. C., Torquebiau, E., Detlefsen, G., Gauthier, M., \& Buttoud. G. (2020). Improved Policies for Facilitating the Adoption of Agroforestry.

https://www.intechopen.com/books/agroforestry-for-biodiversity-and-ecosystem-servi ces-science-and-practice/improved-policies-for-facilitating-the-adoption-of-agroforest ry

Plunkett, M. D., \& Gaisford, J. D. (2000). Limiting Biotechnology? Information Problems and Policy Responses. Current Agriculture, Food \& Resource Issues, No. 1, 21-28.

Tawari, C. C., \& Davies, O. A. (2009). The Relationship of Fisherfolks Characteristics to Technologies Adoption in Niger Delta, Nigeria. Ozean Journal of Applied Sciences, 2, 361-369. 